\title{
Ski Orienteering Disciplines \\ as the Most Prospective for the Program of the OWG
}

\author{
Alexander Yu. Bliznevskiy*, \\ Anna A. Khudik, Valentina S. Bliznevskaya, \\ Sergey V. Khudik and Elena V. Vinnikova* \\ Siberian Federal University \\ 79 Svobodny, Krasnoyarsk, 660041, Russia
}

Received 01.09.2015, received in revised form 04.10.2015, accepted 24.10.2015

The article reviewed the process of expansion program of the Olympic Games in accordance with the rules of the Olympic Charter. The level of development and the advantages of a ski orienteering disciplines are presented for inclusion in the program of the Olympic Winter Games 2022.

Keywords: Olympic Winter Games, kind of sports, international sports federations, the Olympic Games Program, ski orienteering.

DOI: 10.17516/1997-1370-2015-8-11-2233-2236.

Research area: pedagogy.

Relevance: Olympic movement has been developing for 120 years. The Olympic Charter is the main document of rules for the global multisport event for many years, which is periodically updated by the International Olympic Committee (IOC). In particular, the leadership of the IOC adjusted standards for inclusion or exclusion of sports and sport disciplines. According to the new principles of the Olympic movement, approved at the 127th IOC Session in Monaco, now the organizer of the Games has the ability to offer new sports for inclusion in the Olympic program. At the IOC Session which ended July 31, 2015 in Kuala Lumpur (Malaysia), Beijing was determined as a host city of the 2022 OWG.
According to paragraph 6.2 of the Olympic Charter, "only sports competitions between sportsmen who are on the natural snow surface or smooth ice can be recognized as winter sport."

The disciplines of ski orienteering, developed by the InternationalOrienteering Federation(IOF), based at the founding congress in Copenhagen (Denmark) in 1961, are absolutely satisfy this formulation. The first world championship in Ski Orienteering was held in1975 in Finland. Two years later, on 79 IOC Session June 15-18, 1977 in Prague the sport was recognized by the International Olympic Committee.

According to these circumstances, the aim of this study was to determine the prospects for

(C) Siberian Federal University. All rights reserved

* Corresponding author E-mail address: bliznevsky58@mail.ru 
ski orienteering disciplines for inclusion in the program of the Olympic Winter Games, scheduled to be held in 2022 .

The methodology of the study. Based on the analysis of the winter sports disciplines cultivated in the world and recognized by the IOC, archival materials, current legal materials IOC and the Olympic Charter, the comparative analytical method and the ranking show the evolution of the Program of the Olympic Winter Games content and identify the prospects for ski orienteering inclusion.

Results and discussion. From 1924 to 2014 twenty one Olympic Winter Games were taken place. So, on the first OWG in France in Chamonix had been played 15 sets of medals in 8 sports. Each sport includes one or more sports disciplines (part of the sport, which includes one or several events). In turn, each type of competition is a competition, culminating in the distribution of places and awarding of medals.

Dynamics of changes in the Program of the Olympic Winter Games is presented in Table. 1. Its findings suggest that the OWG program expanded with new sports disciplines, which had already been included in their sports, than replenished with new sports. At the same time, the majority of sports, included in the program, is practically exhausted the potential for growth of the Olympic representation.

As a result, last OWG program in Sochi in 2014 included 15 sports of seven International Sports Federations, where 98 sets of medals were awarded. Table 2 is a list of international sports federations and sports of the Program, as well as the number of components of its sports disciplines and types of competitions.

While 98 sets of medals for the Olympic Games is not the limit. For comparison, the rich program of the OWG and the OG, it is obvious that the winter sports forum has significant reserve to expand the program. For example, at the 2012 Olympic Games in London 26 sports (39 sports disciplines) were presented and 302 sets of medals were competed, which indicates the obvious imbalance in the program of the OG and OWG. Although any of Olympic Games according to p. 32 of the Olympic Charter may lasted for sixteen days.

As you know, the Program OWG and OG can expand sports recognized by the International Olympic Committee in accordance with article 29 of the Olympic Charter. These sports are included in the Association of International Sports Federations recognized by the IOC (ARISF), which has 35 sports at the beginning of 2015. Our analysis of the sports disciplines of sports showed that only 5 sports are winter sports disciplines, which can expanded OWG program in Beijing.

Table 3 shows the timing of foundation international sports associations of possible sports for inclusion in the program of the Olympic Winter Games in 2022, the amount of national sports federations, included in its composition, as well as the timing of the winter sports disciplines in the cultural program of the Olympic Winter Games of last years.

International Orienteering Federation is included in their composition and can rightly claim to include its disciplines in winter program of the up coming 2022 OWG. Regulatory requirements of the International Olympic Committee on the main points of the International Orienteering Federation has made - this is a popularity, international recognition, accessibility. According to the statistics of membership in the International Orienteering Federation : in 1961 it consisted of only 10 European countries, it now has already had 79 national federations, representing all continents, which respectively reflected on the amount of involved. The World Championships in ski orienteering in Austria in 1998 and in Sweden in 2011 became the most representative of the number of participants. It was attended by sports 
delegations from 28 and 30 countries - almost all Europe, Scandinavia, the USA, Canada, Japan, and Australia. Besides, ski orienteering (thanked for IOF efforts) was presented as a kind of a show at the Olympic Winter Games in 1998 in Nagano (Japan).

Entertainment and the attractiveness of the show of competitions in the disciplines of ski orienteering is not less than the cross-country skiing and biathlon. Most of the international competitions in ski orienteering in the new millennium carried out on the ski stadium and biathlon complex, using their competitive routes and preparing additional networks for ski course planning. The additional trails are laid on the basis of the possibility of place around the ski stadium and have certain criteria: very wide tracks of more than $3 \mathrm{~m}$; wide tracks 1.5-3.0 m; tracks wide 0.8$1.2 \mathrm{~m}$; slow tracks $0.8-1.0 \mathrm{~m}$ wide. Any additional tracks are prepared without cutting the ski trail according to the rules of the competition.

The specialty of the competition is in having maps, given by the organizers of the competition, and the compass, the only navigational equipment, which athletes can use. Athlete establishes a map in a special device that fits over the breast and firmly fixes.

The essence of competitive activity in the ski orienteering is in passing through a series of control, mapped in the form of circles (and installed on the ground) in a strictly defined order. Straight lines connect the circle. Athlete randomly chooses the path of movement between control points and implements it. The result is determined by the time of passage of the race and approved after documenting the passage through all the controls in the specified order on the map.

The distance for ski orienteering should be designed so that the athlete should use trails of varying gradations, forcing him not only permanently solve problems of orientation, but also change the speed, demonstrating the different elements of the ski course techniques, including only ski orienteering specific. The price of the irrational choice of movement variant between control points can be very high. Often, making a wrong decision and realizing the mistake, it is impossible to adjust the route, which is limited by ski slopes. Modern technologies allow to see the way of the athletes throughout the race by GPSdevices and evaluate the options of movement and mistakes. It makes ski orienteering sport excellent for TV broadcasts.

Today at the World Championships in ski orienteering nine sets of medals in 5 sports disciplines are competed. The list of disciplines in the programs of international competitions of different level ski orienteering disciplines (SKI-O) is contained in the Rules of IOF events, the latest version of which is valid from January 1, 2015 and are classified by the expected time of winners per min .:

- Long - women 75-90 min.; men 95-100 $\min$.

- Middle - women and men 40-45 min.

- Sprint - women and men 10-15 min.

- 3 stages Relay - women and men 100 min. for 3 stages;

- 6 stages (Sprint-Relay) - women + men36-48 min. for 6 stages.

Today more "medal-making" sports in the Olympic program have a significant influence on the unofficial team standings among the participating countries.

Conclusion. The evolution of the international Olympic movement and the intension of the Olympic Winter Games program, indicate the possibility of a significant expansion of it by including new sports. In addition, new sports inclusion in the OWG program will not prevent increasing the number of sports disciplines that make it today. Ski orienteering disciplines are very promising for the OWG program today. 
Although, according to the Olympic addition to the five disciplines of the program of Charter, the Olympic Games are competitions the world championships, the emergence of new between individual athletes and not between the national teams, the so-called unofficial team standings between countries-participants of the Games in the number of different medals are really important. According to this fact, ski orienteering is specially interesting, where in disciplines is also possible for ski orienteering: Pursuit (Gunderson method) super sprint, extralong, mixed relay $2+2$. That is why today the leadership of IOF makes maximum effort to include ski orienteering disciplines in the future OWG program.

\title{
References
}

Bliznevskiy, A.Y., Bliznevskiy, V.S. (2011). Winter Sports for Olympic Program Addition. Journal of Siberian Federal University. Humanities \& social sciences, 4(3), 309-314.

Competition rules for International Orienteering Federation (IOF) ski orienteering events. Approved by IOF Ski Orienteering Commission, valid from 1 May 2015, 50 p.

International Specification for Ski Orienteering MapsISSkiOM. Approved by IOF Ski Orienteering Commission, valid from 1 December 2014. Astoria, $10 \mathrm{p}$.

Olympic Agenda 2020. Approved at the 127 th IOC Session on 9 December 2014. Monaco, $25 \mathrm{p}$.

Olympic Chapter. Confirmed by $127^{\text {th }} \mathrm{IOC}$ session, 8 December 2014. Lozanna, DidWeDo S.à.r.l., $108 \mathrm{p}$.

Regulations of International Sports federation Association. Recognized by IOC, confirmed by General Assembly of ARISF 6 April 2006, 11 p.

\section{Дисциплины лыжного ориентирования \\ как наиболее перспективные \\ для включения в Программу 3ОИ}

\author{
А.Ю. Близневский, А.А. Худик, \\ В.С. Близневская, С.В. Худик, Е.В. Винникова \\ Сибирский федеральный университет \\ Россия, 660041, Красноярск, пр. Свободныій, 79
}

В статье рассматривается порядок расширения Программы Олимпийских игр согласно правилам Олимпийской хартии. Представлены уровень развития и преимущества дисииплин лыжного ориентирования для включения в Программу зимних Олимпийских игр 2022 г.

Ключевые слова: зимние Олимпийские игры, виды спорта, международные спортивные федерачии, Программа Олимпийских игр, лыжное ориентирование.

Научная специальность: 13.00.00 - педагогические науки 